\title{
Pengaruh Variasi HA-TCP (Hydroxy Apatit-Tricalcium Pospat) Terhadap Biokomposit (HA:TCP)-Gelatin-CMC Sebagai Injectable Bone Subtitute (IBS)
}

\author{
Gani Purwiandono $^{a}$, Hera Julita ${ }^{b}$, Dita Adi Saputra ${ }^{c}$ \\ ${ }^{\mathrm{a}, \mathrm{b}}$ Program Studi Kimia, Universitas Islam Indonesia \\ ${ }^{c}$ Badan Pengkajian dan Penerapan Teknologi, Serpong \\ email: gani_purwiandono@uii.ac.id
}

\begin{abstract}
The synthesis of biocomposite (HA:TCP) - Gelatine - CMC for bone filler material has been carried out. In this research, the ratio of HA and TCP was varied as follows: 70:30, 50:50 and 40:60. The decrease of HA and the increase of TCP concentration will decrease the density, increase the percentage of porosity and swelling. The best composition for the synthesis was obtained for sample B with the ratio of HA:TCP $=50: 50$. For sample $\mathrm{B}$, the synthesized biocomposite has the density

of $1.67790 \mathrm{gr} / \mathrm{cm}^{3}$, porosity of $78.64 \%$, tension of $10.14 \mathrm{MPa}$, swelling ability $46.85 \%$ and the sample mass degradation percentage of $8.1 \%$. The composition used for the biocomposite synthesis in this research was suitable to be applied as bone filler material which needs a dense pores and high tension.
\end{abstract}

Key Words: Injectable bone subtitute, hydroxyapatite, tricalcium phospate

\begin{abstract}
ABSTRAK
Telah dilakukan penelitian pembuatan biokompsit (HA:TCP)-Gelatin-CMC yang digunakan sebagai material bone filler. Penelitian ini menggunakan variasi pada HA dan TCP, yakni 70:30, 50:50 dan 40:60. Diperoleh penurunan komposisi HA dan peningkatan TCP akan menurunkan nilai densitas, meningkatkan persentase porositas dan pemekaran (swelling). Komposisi terbaik terdapat pada variasi sampel B dengan perbandingan HA:TCP $=50: 50$ yang memiliki nilai densitas 1,67790 gr/ $\mathrm{cm}^{3}$, porositas 78,64\%, kuat tekan 10,14 MPa, swelling ability 46,85\% dan persentase degradasi massa sampel $8,1 \%$. Komposisi sampel pada penelitian ini cocok untuk aplikasi tulang yang memerlukan pori rapat dengan kuat tekan yang tinggi.
\end{abstract}

Kata kunci : Injectable bone subtitute, hidroksiapatit, trikalsium fosfat

\section{Pendahuluan}

Pada tahun 2009 osteoporosis

menduduki peringkat kedua di bawah

penyakit jantung sebagai masalah

kesehatan utama dunia. Menurut data

Internasional Osteoporosis Foundation

(IOF) lebih dari $30 \%$ wanita di seluruh dunia mengalami resiko seumur hidup untuk patah tulang akibat osteoporosis, bahkan mendekati $40 \%$, sedangkan pada pria, resikonya berada pada angka 13\% (WHO, 2009). Menurut Departemen Kesehatan RI pada tahun 2009, dampak osteoporosis di Indonesia sudah dalam tingkat yang harus diwaspadai, yaitu 
mencapai $19,7 \%$ dari populasi (DEPKES, 2009).

Material biokeramik kalsium fosfat (CaP) telah banyak digunakan dalam bidang ortobedi sebagai material pengganti tulang. Kalsium fosfat yang paling banyak digunakan adalah hidroksiapatit (HA) dengan rumus kimia $\mathrm{Ca}_{5}\left[\mathrm{PO}_{4}\right]_{3} \mathrm{OH}$, dan trikalsium fosfat (TCP) dengan rumus kimia $\mathrm{Ca}_{3}\left[\mathrm{PO}_{4}\right] 2$. Meskipun keduanya memiliki komposisi kimia yang sama kedua material ini memiliki perbedaan dalam sifat resorbabilitas (sifat mampu diserap) pada jaringan biologis (Victoria and Gnanam, 2012).

HA dan TCP bersifat bioaktif dan osteointegratif ketika diimplan kedalam tubuh, namun HA cenderung bersifat nonresorbable dan bioinnert sementara TCP bersifat resorbable. Biokeramik yang ideal tidak hanya bioaktif tetapi harus juga bersifat bioresorbable, untuk memberi ruang tumbuhnya jaringan tulang baru. Penggabungan HA sifat bioaktifnya dan TCP sifat bioresorbable dengan komposisi tertentu lebih dapat mengontrol proses resorpsi dan substitusi biomaterial tulang (Aoki, 1991).

Keseimbangan fase lebih stabil HA dan TCP lebih mudah larut, memungkinkan untuk secara bertahap mengontrol pembubaran dalam tubuh, pembibitan pembentukan tulang baru seperti melepaskan ion kalsium $\left(\mathrm{Ca}^{2+}\right.$ dan fosfat $\left(\mathrm{PO}_{4}{ }^{3-}\right)$ ke dalam media biologis (Pierre, 2006). Pada penelitian material dari keramik kalsium fosfat HA/TCP dengan $80 \%$ hidroksiapatit (HA) dan $20 \%$ trikalsium fosfat (TCP), memiliki kekurangan yaitu kekuatan mekanik yang rendah (Levin, et al., 1975).

Kekuatan mekanik yang rendah diperlukan material penguat (reinforced) yang memiliki sifat mekanik lebih tinggi. Beberapa peneliti telah mengembangkan suatu komposit dengan polimer untuk memperbaiki sifat mekaniknya (Kashiwazaki, et al., 2009). Bahan komposit dari polimer alam merupakan generasi biomaterial masa datang yang penting dikembangkan dalam bidang rekayasa jaringan (tissue engineering).

Salah satu polimer alam yang dapat digunakan untuk memperkuat suatu komposit adalah gelatin. Gelatin adalah protein yang diperoleh dari jaringan kolagen hewan yang terdapat kulit, tulang dan jaringan ikat. Gelatin sebagai polimer yang berasal dari alam bahan biodegradable, biokompatibel dan tidak beracun. gelatin banyak digunakan sebagai pengisi ruang yang memiliki kemampuan 
reversible dari fase sol ke gel atau sebaliknya, mengembang dalam air, membentuk film, mempengaruhi viskositas suatu bahan dan melindungi sistem koloid (Hajrawati, 2006).

Perut et al., (2011), telah berhasil mengetahui bahwa adanya gelatin dalam injectable bone substitute mampu mendukung pertumbuhan sel tulang baru dan penempelannya. Sehingga pada penelitian ini, akan dilakukan sintesis komposit HA-TCP-gelatin-CMC dengan variasi komposisi pada HA/TCP. Metode yang digunakan berdasarkan dissolutionprecipitation sebagai injectable bone substitute.

\section{Tujuan Penelitian}

Tujuan dilakukan penelitian ini adalah mengetahui komposisi optimum HA dan TCP pada komposit HA-TCPgelatin-CMC.

\section{Metode Penelitian}

Penelitian dilakukan di Laboratorium Biomaterial Pusat Teknologi Material BPPT Serpong Tanggerang Selatan.

Preparasi HA-TCP. Preparasi serbuk HA-TCP dilakukan dengan pencampuran secara mekanik serbuk HA Gamping (BPPT, Indonesia) dan serbuk TCP (BPPT, Indonesia). Pada penelitian ini dilakukan variasi tiga komposisi HA/TCP yang berbeda, antara lain: Sampel A adalah HA-TCP dengan perbandingan serbuk HA:TCP 70:30. Sampel B adalah HA-TCP dengan perbandingan serbuk HA:TCP 50:50. Sampel C adalah HA-TCP dengan perbandingan serbuk HA:TCP 40:60.

Preparasi HA-TCP diawali dengan dengan membuat perbandingan HA-TCP dan aseton 1:2. Campuran Diaduk menggunakan magnetik stirer dengan kecepatan $600 \mathrm{rpm}$ dan dimasukkan ke dalam oven dengan temperatur $50^{\circ} \mathrm{C}$ selama 17 jam.

\section{Pembuatan Larutan Gelatin.} Larutan gelatin $10 \%(\mathrm{w} / \mathrm{w})$ dibuat dengan pencampuran 4 gram serbuk gelatin, 4 gram asam sitrat dan 2 gram $\mathrm{KH}_{2} \mathrm{PO}_{4}$ dalam 30 gram akuades. Larutan kemudian dihomogenkan pada temperatur $40-50^{\circ} \mathrm{C}$ selama 45 menit.

\section{Pembuatan Larutan CMC} Larutan CMC 2\% (w/w) dibuat dengan melarutkan 0,4 gram CMC dalam 19,6 gram akuades pada temperatur $80-100^{\circ} \mathrm{C}$ selama 60 menit.

Sintesis komposit HA-TCPGelatin-CMC. Dilakukan pencampuran larutan gelatin $10 \%(\mathrm{w} / \mathrm{w})$ dengan larutan CMC $2 \% \quad(w / w)$ pada perbandingan 
gelatin: $\mathrm{CMC}=4: 1$. Campuran diaduk dengan kecepatan 600 rpm selama 10 menit hingga homogen. Dilakukan penambahan serbuk HA-TCP sesuai dengan variasi komposisi yang telah ditentukan (Sampel A, B dan C), dimasukkan ke dalam alat syiringe untuk dicetak dalam pencetak komposit HATCP-Gelatin-CMC.

Karakterisasi material komposit, karakterisasi meliputi: uji densitas dan porositas, uji swelling ability, uji degradasi, dan uji tekan.

Uji Densitas dan porositas. Pengujian densitas dan porositas sampel dilakukan dengan mengukur massa sampel awal (A) setelah itu mengukur massa sampel dalam air (B) dan mengukur sampel basah (C). Nilai densitas sampel dapat didapatkan melalui persamaan:

$\rho=\frac{\mathrm{A}}{\mathrm{A}-\mathrm{B}}(\rho 0-\mathrm{d})+\mathrm{d}$, nilai porositas sampel dapat didapatkan melalui persamaan:

$\mathrm{p}=\left(\frac{\mathrm{C}-\mathrm{A}}{\mathrm{A}-\mathrm{B}}\right) \times 100 \%$

Uji swelling ability dan degradasi. Uji pemekaran (swelling) dilakukan dengan cara merendam scalfolld dalam larutan SBF (Simulated Body Fluid). Ditimbang berat sampel scaffold mulamula (Wo). Timbang berat scaffold setelah direndam (W1). Sampel dikeringkan dalam desikator selama 24 jam, kemudian dikeluarkan dan ditimbang (W2). Selisih berat antara berat mula-mula (Wo) dan setelah direndam (W1) dinyatakan dalam $\%$, merupakan harga tingkat penyerapan air atau tingkat pemekarannya/swelling, dinyatakan dalam persamaan. Tingkat penyerapan air $(\%)=\frac{\mathrm{w} 1-\mathrm{w} 0}{\mathrm{wo}} \times 100 \%$, sedangkan tingkat kehilangan berat atau degradasi dinyatakan dalam persamaan tingkat penyusutan berat sampel (\%) $=\frac{w_{0}-w_{2}}{w_{0}} \times 100 \%$.

Tingkat penyerapan air yang tinggi menunjukkan kemampuan swelling komposit matriks yang tinggi, sedangkan tingkat penyusutan berat yang rendah menunjukkan sifat penyusutan/degradasi komposit matriks yang rendah.

Pengujian kuat tekan dilakukan dengan menggunakan sampel berbentuk silinder. Sampel ditempatkan pada bagian penekan mesin uji tekan.

\section{Pembahasan}

Telah dilakukan sintesis komposit HA-TCP-gelatin-CMC yang diaplikasikan sebagai injectable bone substitute dengan perbandingan variasi komposisi hidroksiapatit dan tri-calcium phospate 70:30 (sampel A), 50:50 (sampel B) dan 
40:60 (sampel C). Perbandingan HA-TCP, gelatin dan CMC yang digunakan pada masing-masing sampel adalah 4:4:1. Karakterisasi yang diuji meliputi uji densitas, porositas, sweliing ability, uji kuat tekan dan uji degradasi dengan simulated Body Fluid (SBF).

Uji Densitas dan porositas. Pengujian densitas dan porositas komposit HA-TCP-gelatin-CMC dengan variasi komposisi HA dan TCP dapat menurunkan densitas dan meningkatkan porositas komposit HA-TCP-gelatin-CMC yang dihasilkan sebagaimana pada Tabel 1.

Tabel 1. Hasil Uji densitas dan porositas pada komposisi sampel

\begin{tabular}{|c|c|c|}
\hline Sampel & $\begin{array}{c}\text { Densitas } \\
\left(\mathrm{g} / \mathrm{cm}^{3}\right)\end{array}$ & Porositas \\
\hline A & 1,72311 & $53,40 \%$ \\
\hline B & 1,67790 & $78,64 \%$ \\
\hline C & 1,59498 & $88,41 \%$ \\
\hline
\end{tabular}

Pada Tabel 1 variasi komposisi HA:TCP menunjukkan hasil densitas yang kecil dan tidak sesuai dengan densitas tulang yang memiliki densitas $3.1-3.2$ $\mathrm{g} / \mathrm{cm}^{3}$ (Wilman, 1996). Penelitian yang dilakukan oleh Jiang Hang (2009), menyatakan bahwa sela-sela kosong pada komposit akan dimasuki sel-sel hidup yang akan tumbuh, sehingga nantinya sampel akan mampu menyesuaikan diri dan memiliki densitas yang sama dengan tulang yang diimplannya.

Porositas yang dihasilkan pada sampel A yaitu 53,40\%, sampel B 78,64\% dan sampel C 88,41\% yang telah sesuai dengan porositas tulang cancellous yaitu 30-90\%, jika porositas semakin meningkat maka sel jaringan sekitarnya mudah masuk ke dalam dan berproliferasi didalamnya dan akan meningkatkan sifat osteokonduktif dari matriks sebagai scaffold dari sel-sel sekitarnya dari resipien (Hillig et al., 2008).

Matriks sampel mengandung gelatin sebagai protein tulang yang dapat membantu berkembangnya sel jaringan untuk membentuk challus, yang selanjutnya bereaksi dengan kalsium dengan bantuan osteoblas membentuk tulang baru (Wilman, 1996).

Uji Swelling dan degradasi, pengujian sifat degradasi dari sampel basah, dilakukan perendaman dari sampel dalam larutan SBF. Hasil uji ditunjukkan pada Tabel 2.

Tabel 2. Hasil Uji swelling ability dan

\begin{tabular}{|c|c|c|}
\hline \multicolumn{3}{|c}{ degradasi } \\
\hline A & $30,79 \%$ & $7,33 \%$ \\
\hline B & $46,85 \%$ & $8,1 \%$ \\
\hline C & $55,37 \%$ & $8,25 \%$ \\
\hline
\end{tabular}


Tabel 2 menunjukkan bahwa dengan variasi komposisi HA dan TCP menyebabkan densitas komposit HA-TCPgelatin-CMC menurun dan meningkatnya porositas. Meningkatnya porositas menyebabkan air/cairan akan semakin mudah untuk berdifusi ke dalam sampel sehingga pemekaran (Swelling) semakin meningkat dan sampel mudah untuk terdegradasi.
Uji Tekan. Merupakan uji untuk mengetahui sifat komposit dalam pemenuhan persyaratan bahan sebagai pengisi tulang. Menurut ketentuan persyaratan bahan dapat digunakan sebagai pengganti tulang jika memiliki kuat tekan antara 2-12 $\mathrm{MPa}$ pada tulang canceollus dan untuk tulang cortical memiliki kuat tekan antara 30-160 Mpa (Wilman, 1996). Nilai uji tekan sampel ditunjukkan pada Tabel 3.

Tabel 3. Hasil Uji Tekan

\begin{tabular}{|c|c|c|c|c|c|}
\hline Komposisi & Sampel & $\begin{array}{c}\text { Max.Stress } \\
(\mathrm{MPa})\end{array}$ & $\begin{array}{c}\text { Max.Force } \\
(\mathrm{N})\end{array}$ & $\begin{array}{c}\text { Max.Stroke } \\
(\mathrm{mm})\end{array}$ & $\begin{array}{l}\text { Rerata Max. } \\
\text { Stress }(\mathrm{MPa})\end{array}$ \\
\hline \multirow{3}{*}{ A } & 1 & 12,35 & 730,52 & 1,57 & \multirow{3}{*}{13,53} \\
\hline & 2 & 14,90 & 848,65 & 1,65 & \\
\hline & 3 & 13,34 & 757,14 & 1,52 & \\
\hline \multirow{3}{*}{ B } & 1 & 9,77 & 638,21 & 1,71 & \multirow{3}{*}{10,14} \\
\hline & 2 & 10,38 & 598,99 & 1,67 & \\
\hline & 3 & 10,27 & 686,84 & 1,77 & \\
\hline \multirow{3}{*}{$\mathrm{C}$} & 1 & 3,31 & 234,09 & 1,46 & \multirow{3}{*}{3,76} \\
\hline & 2 & 4,32 & 293,85 & 2,06 & \\
\hline & 3 & 3,66 & 259,56 & 1,46 & \\
\hline
\end{tabular}

Pada variasi komposisi HA dan TCP berpengaruh pada kekuatan komposit yang dihasilkan. Pada Tabel 2 diketahui adanya penurunan kekuatan komposit yang disebabkan pengurangan dan penambahan komposisi HA dan TCP. Pada sampel A mengahasilkan kekuatan sebesar 13,53 MPa, sampel B menghasilkan 10,14 MPa dan sampel C menghasilkan 3,76 MPa. Hal tersebut telah sesuai dalam range nilai kuat tekan tulang cancellous yaitu 2-12 MPa.

\section{Kesimpulan}

Kesimpulan dari hasil penelitian menunjukkan:

1. Penurunan komposisi HA dan peningkatan TCP akan menurunkan nilai densitas dan meningkatkan persentase porositas yang diikuti 
dengan meningkat pemekaran (swelling) sehingga degaradasi meningkat dan menurunnya nilai kuat tekan pada komposit yang dihasilkan.

2. Komposisi terbaik terdapat pada variasi sampel B dengan perbandingan HA:TCP $=50: 50$ yang memiliki nilai densitas $1,67790 \mathrm{gr} / \mathrm{cm}^{3}$, nilai porositas 78,64\%, kuat tekan 10,14 $\mathrm{MPa}$, swelling ability $46,85 \%$ dan persentase degradasi massa sampel 8,1\%.

\section{Ucapan Terimakasih}

Penulis mengucapkan terima kasih kepada Pusat Teknologi Material BPPT (Badan Pengkajian dan Penerapan Teknologi) Serpong yang telah memberikan arahan dan izin dilakukannya penelitian ini dalam program (PKL) Praktek Kerja Lapangan.

\section{Pustaka}

Aoki, H., 1991. Science Medical Applications Of Hydroxyapatite, JAAS, Tokyo

DEPKES, 2009, Waspadai osteoporosis di Indonesia.

http://www.depkes.co.id/index.php. html. diperoleh tanggal 26 Maret 2016

Hajrawati, 2006, Sifat Fisik dan Kimia Gelatin Tulang Sapi dengan Perendaman Asam Klorida pada Konsentrasi dan Lama Perendaman yang Berbeda, Thesis, Sekolah Pascasarjana Institut Pertanian Bogor, Indonesia
Kashiwazaki H., Yusuke K., Atsushi M., Keisuke Y., and Tadhasi I., 2009, Fabrication of porous chitosan/ hydroxyapatite nanocomposites: their mechanical and biological properties, Bio. Med. Mat. And Eng., 19, 133-140

Levin, M.P., Getter, L., and Cutright, D.E., 1975, A comparison of iliac marrow and biodegradable ceramic in periodontal defects. J. Biomed. Mater. Res. 9, 183

Perut, F., Montufar, E. B., Ciapetti, G., Santin, M., Salvage, J., Traykova, T., Planell, J. A. andGinebra, M. P., 2011, Novel Soybean/ GelatinBased Bioactive and Injectable Hydroxyapatite Foam: Material Properties and Cell Response, Acta Biomaterialia 7 Inc Elsevier Ltd, Italia: $1780-1787$

Pierre, C., 2006, Injectable calcium phosphate scaffold and bone marrow graft for bone reconstruction in irradiated areas: An experimental study in rats, Biomaterials, 27, 4566-4572

Victoria, E.C., and Gnanam, F.D., 2012, Synthesis And Characterisation Of Biphasic Calcium Phosphate, Trends. Biomater. Artif. Organ, Vol.16 (1) PP $12-14$

Wilman, G., 1996, Medical Grade Hydroxyapatite. State of The Art, Bristh Ceramic Transaction, Vol. 95. No 5

WHO., 2009.Osteoporosis ancaman kesehatan penduduk dunia. http://www.who.org/program/osteopo rosis/index.html, Diakses pada tanggal 26 Maret 2016 